\title{
Personal recollections of Sidney Dyke in the early years of the A.C.P.
}

\author{
CUTHBERT E. DUKES
}

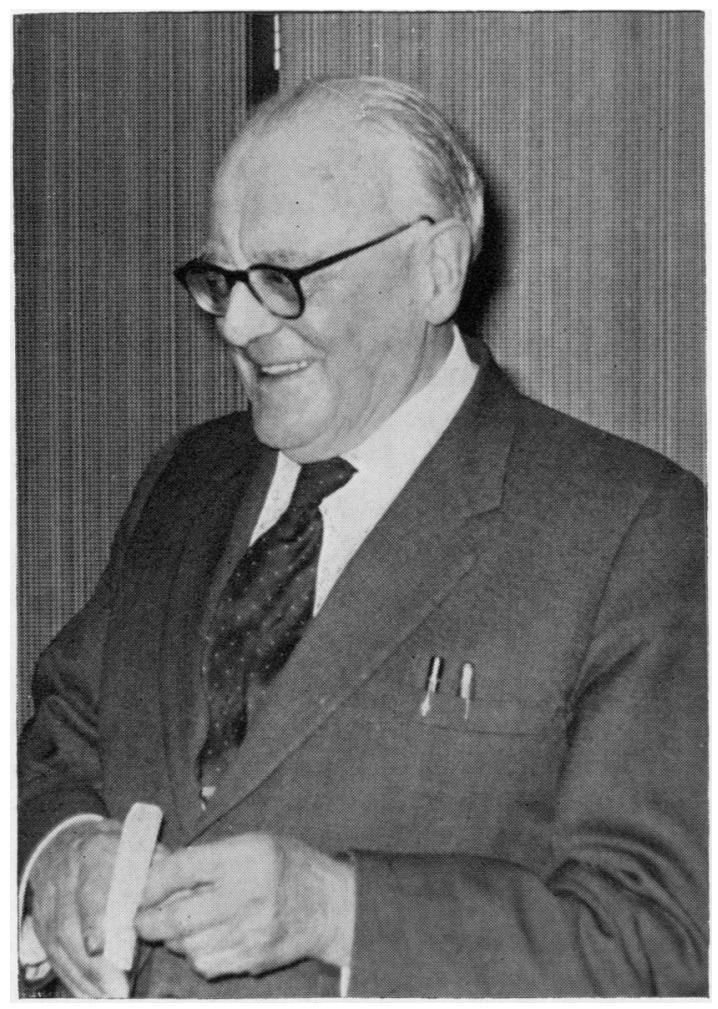

Sidney Campbell Dyke, founder of the A.C.P., celebrates his 80th birthday on 5 September 1966. We all wish him continued good health and many happy returns of the day.

In the early years of the A.C.P. everyone who attended our meetings knew Dyke personally: one might almost say, intimately. But nowadays there must be many of our members who know him only by sight or by reputation. Therefore it may be of interest to recall the impression he first made on those of us who worked closely with him nearly forty years ago.

I must begin by recalling that the A.C.P. was founded in 1927 but that early in 1926 Dyke, entirely on his own initiative, had sent exploratory letters to a number of pathologists, suggesting the formation of an organization for bettering the condition of pathological practice and improving the status of clinical pathologists. Following this preliminary enquiry Dyke sent a letter to the British Medical Journal and Lancet (1 January 1927) announcing the intention of holding a meeting in London to consider the interests of those engaged in the practice of pathology.

This meeting was held at the London School of Medicine for Women on 7 January 1927. It was attended by 33 pathologists who decided then and there to form an association 'to develop the application of pathology in relation to medicine and to protect the interests of those engaged in its study and practice'.

These are the bare facts. For a more detailed account I think the most easily available source is W. D. Foster's 'Short history of clinical pathology' (1961). Chapter VIII, entitled: 'Organization of clinical pathology to present day' was written by Dyke and so includes his own account of the origins of the A.C.P.

S. C. Dyke was just over 40 years of age when he founded the A.C.P. He was already a familiar figure to those of us who attended meetings of the Pathological Society, which had of course, been in existence for many years. He looked then (and still looks) astonishingly like his representation on the foundation medal struck in his honour at the time of our 21 st anniversary in 1948. He has always had the same eager, voluble and emphatic way of speaking at public meetings: persuasive and effective.

From the earliest beginnings we always held two scientific meetings a year, one in London and one in the provinces. The meetings were both social and scientific, as Dyke has himself recorded: 'A very important part of these meetings was the dinner at which in those happy days there were no set speeches and no invited speakers: members ate together and it was understood that after the dinner any one was at liberty, with the permission of the chairman, to air his opinions and receive the views of his fellow members: these after-dinner symposia proved of the greatest value in formulating the early policies of the association.' 
Our committee meetings also were rather unconventional in character in those early years. They provided Dyke with ample opportunity for 'airing his opinions' which he often did with wit and wisdom in picturesque language. He was fond of illustrating his remarks with Biblical quotations and allusions to theological controversies of bye-gone days. But he always endeavoured to be precise and exact in his choice of words. Le mot juste pleased him greatly. For instance, I remember one characteristic outburst which fortunately I can record verbatim because I made a note of it at the time. It was at the end of one of those long discussions on the status of the clinical pathologist which occupied so much of the time of our Council meetings in the early nineteen thirties. Suddenly Dyke exclaimed: 'Clinical pathology has its own contribution to make towards the entelechy of medicine. Yes, that is the word. Go and look it up if you don't know what it means.'

I was one of those who, after returning home, had to consult a dictionary to learn that the word 'entelechy' means 'that which gives form or perfection to a thing.' This was what clinical pathology was to be to the profession of medicine! If Dyke had simply said 'clinical pathology completes the picture' I should have forgotten it long ago. As it is I have remembered the word 'entelechy' for more than 30 years.

I am sure that in its early years the success of the A.C.P. owed much to Dyke's eloquence, especially when more or less impromptu. We always listened attentively to his contributions to the discussions at our scientific meetings and to the Annual Report which he delivered with so much gusto each year. He always kept his audience in a good humour: a rare gift.

The A.C.P. also owed much to Dyke's journalistic talent, though I must say that in my opinion our founder was more effective as a speaker than as a writer. But he appreciated the importance of the written word: witness his influence in the initiation of this Journal and of that hardy perennial 'Recent advances in clinical pathology'. However, these are fruits of a later period. I must return to recollections of the early years.

Dyke became the recognized spokesman of the A.C.P. in all communications to the medical press. He wrote frequently and forcibly for the correspondence columns of the British Medical Journal and Lancet. I hope that someday someone will make a collection of Dyke's letters. At present I can only contribute two which I still remember and have been able to trace. I quote them as examples of 'Dykian' wit and wisdom.

From the 'British Medical Journal' (13 July 1935)

'Most workers in diagnostic laboratories have at $\vec{\sigma}$ one time or another been embarrassed by being $\cong$ regarded as priests of a peculiar $j u-j u$ which, in return $c$ for a suitable offering of a piece of meat, or a bottle $\vec{\circ}$ of urine, will make oracular utterance.'

From the 'British Medical Journal' (3 September 1938)

'The impression exists . . . that the beginning and end of clinical pathology is the examination in a? laboratory of a specimen from the patient without $\overrightarrow{0}$ reference to that patient. The pathologist was, and $i$ still sometimes is, regarded as a sort of mumbo- $\vec{\omega}$ jumbo who, from within his laboratory shrine, will, on receipt of appropriate offering of blood, excrement, or tissue, make oracular utterance.'

I have recalled my recollection of Dyke's style of $\frac{\mathbb{}}{\mathbb{O}}$ speaking and writing because these were very $\frac{\mathbb{D}}{\vec{D}}$ effective in ensuring the success of the A.C.P., but $\bar{Z}$ much more important than these were certain of his $\stackrel{\mathbb{D}}{-}$ personality characteristics to which I will refer in $\vec{\oplus}$ conclusion.

Sidney Dyke has always been a very sociable person and easy to get on with. He soon got to know everyone who turned up at our meetings and seldom forgot their names afterwards. He remembered where they came from and their special interest in clinical pathology. This was useful because we were a very miscellaneous group in those early years.

Most important of all, Dyke attended all meetings wherever held, always arriving punctually with his big black despatch case bulging with papers. $\mathrm{He}$ must have travelled thousands of miles on behalf of the Association in its first decade.

At committee meetings it was always clear that Dyke had done his 'home work' in advance, but if anything fresh arose unexpectedly he was remarkably quick in the uptake. In fact, it was this and his sound $\mathrm{O}$ judgment that made him our undisputed leader from the beginning.

I hope I have succeeded in recalling the impression Sidney Dyke made on those of us who worked witho him in the early years of the A.C.P. He had many N endearing characteristics. He was a far-sighted man, N but not a mere visionary. He was always a man of $\sigma$ action with the courage of his convictions. And at the age of 80 he is still much the same. 